\title{
Model Matematika Minuman Keras
}

\author{
Muchammad Abrori \\ Program Studi Matematika, Fakultas Sains dan Teknologi, Universitas Islam Negeri Sunan Kalijaga \\ Yogyakarta, Jl. Marsda Adisucipto Yogyakarta 55281
}

Korespondensi; Email: borymuch@yahoo.com

\begin{abstract}
Abstrak
Makalah ini membahas pembentukan model matematika jumlah alkohol sebagai komponen utama minuman keras dalam tubuh pengkonsumsinya. Lambung dan pembuluh darah menjadi dua kompartemen yang menyusun model. Penyusunan model memperhatikan pula pola konsumsi alkohol, yaitu meminum sekali maupun rutin. Selain itu diperhatikan pula kondisi lambung pengkonsumsinya, apakah kosong atau sudah terisi zat makanan. Hasilnya diperoleh model yang dapat digunakan untuk menganalisa perubahan jumlah alkohol baik di dalam lambung maupun di dalam pembuluh darah.
\end{abstract}

Kata Kunci: Model Matematika; Minuman Keras/Alkohol; Solusi Model.

\begin{abstract}
This paper discusses the establishment of a mathematical model the amount of alcohol as a major component in the body pengkonsumsinya liquor. Stomach and blood vessel into two compartments that make up the model. Modeling to pay attention to patterns of alcohol consumption, ie once or regularly drank. Additionally noted also pengkonsumsinya gastric conditions, whether empty or full of nutrients. The result obtained by the model can be used to analyze changes in the number of alcohol either in the stomach or in the blood vessels.
\end{abstract}

Keywords: Mathematical models; Alcohol; Solution Model.

\section{Pendahuluan}

Minuman keras adalah minuman yang mengandung etanol. Etanol adalah bahan psikoaktif yang dengan mengkonsumsinya dapat menyebabkan penurunan kesadaran. Efek yang ditimbulkan setelah mengkonsumsi minuman keras dapat dirasakan segera dalam waktu beberapa menit saja. Dalam jumlah yang kecil, minuman keras akan menimbulkan perasaan relax dan pengguna akan lebih mudah mengekspresikan emosi seperti rasa senang, sedih dan marah.

Bila dikonsumsi dalam volume yang lebih besar, pengkonsumsi minuman ini akan merasa lebih bebas lagi dalam mengekspresikan diri, tanpa ada perasaan terhambat dan menjadi lebih emosional (sedih, senang, marah secara berlebihan). Pengaruh pada fungsi fisik-motorik mulai muncul, yaitu bicara cadel, pandangan menjadi kabur, sempoyongan, inkoordinasi motorik dan bahkan sampai dengan tingkat tidak sadarkan diri. Selain itu kemampuan mental juga mengalami hambatan, yaitu gangguan untuk memusatkan perhatian dan gangguan daya ingat (Chapman 2009 dan George 2004).

Pengkonsumsi minuman keras dapat terancam masalah kesehatan yang serius seperti radang usus, penyakit liver, dan kerusakan otak. Mereka yang sudah ketagihan biasanya mengalami suatu gejala yang disebut sindrom putus alkohol, yaitu rasa takut diberhentikan dari minum alkohol. Mereka akan sering gemetar dan jantung berdebar-debar yang disertai dengan perasaan cemas, gelisah, murung, dan banyak berhalusinasi.

Minuman keras termasuk jenis khamr yang dilarang menurut agama Islam. Hal ini tercantum dalam firman Allah surat Al Maidah ayat 90:

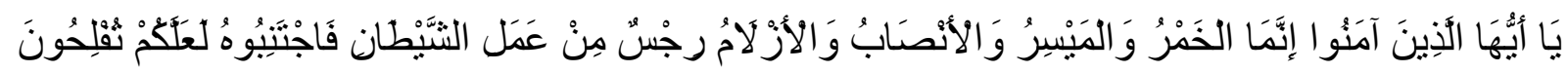


"Hai orang-orang yang beriman, sesungguhnya (meminum) khamar, berjudi, (berkorban untuk) berhala, mengundi nasib dengan panah, adalah termasuk perbuatan syaitan. Maka jauhilah perbuatan-perbuatan itu agar kamu mendapat kebahagiaan".

Di Indonesia, minuman keras juga dilarang menurut undang-undang, yaitu pasal 59 ayat $1 \mathrm{~b}$ jumto pasal 59 ayat 2 UU No.5/1997 tentang Psikotropika jumto pasal 55 ayat 1 ke 1 , pasal 59 ayat 1 huruf e jumto pasal 59 ayat 2 UU No.5/1997 jumto pasal 55 ayat 1 ke 1 KUHP, dan pasal 59 ayat 1 huruf e jo pasal 59 ayat 2 huruf b jumto pasal 55 ayat 1 ke 1 KUHP. Berbagai upaya juga telah dilakukan pemerintah dan elemen masyarakat untuk menghentikan penggunaan minuman terlarang ini.

Model matematika adalah salah satu konsentrasi keilmuan dalam matematika yang berusaha mendekati dan menerjemahkan suatu fenomena dalam kehidupan ke dalam bentuk persamaan matematika yang menggambarkan fenomena tersebut. Dengan menyelesaikan model matematika akan dihasilkan rekomendasi-rekomendasi dari pemecahan masalah yang dimodelkan.

Makalah ini akan mengkaji model matematika asimilasi minuman keras berjenis alkohol dalam tubuh manusia. Kompartemen yang ditinjau dalam model matematika yang akan disusun adalah kadar alkohol dalam lambung dan pembuluh darah pengkonsumsinya. Selanjutnya akan ditinjau pengaruh jenis kelamin dan berat badan pengkonsumsi terhadap jumlah kadar alkohol yang terserap dalam dua kompartemen tersebut. Hal ini didasarkan pada pemodelan matematika pil ekstasi dan sejenisnya yang disajikan dalam Borelli dan Coleman (1996), Faisant et al. (2003), Lee et al. (1997), Muller et al. (2008), Siepmann (2008) dan Tzafriri et al. (2005). Secara berbeda, Bhunu (2015) dan Heck (2007) memodelkan pengkonsumsi alkohol dalam tinjauan komunitas.

Makalah ini disajikan dengan runtutan alur sebagai berikut. Setelah pendahuluan, bagian kedua dari makalah ini menyajikan asumsi-asumsi yang disusun untuk memodelkan beserta dengan sajian model matematika dalam berbagai kasus pengkonsumsian minuman keras. Selanjutnya pada bagian ketiga akan dipaparkan langkah mencari solusi model dan analisis solusi serta interpretasinya dalam tubuh pengkonsumsi minuman keras, baik dari aspek fisik maupun aspek psikis. Terakhir, bagian keempat berisi kesimpulan pembahasan beserta dengan masalah terbuka yang timbul dari permasalahan yang dikaji.

\section{Konstruksi Asumsi dan Model Matematika}

Proses asimilasi minuman keras ke dalam tubuh manusia dapat dijelaskan sebagai berikut. Minuman keras yang tertelan dalam tubuh manusia akan masuk ke dalam lambung dan selanjutnya zat-zat penyusun minuman keras ini akan secara cepat terurai dan menyebar ke dalam pembuluh darah. Kecepatan penyerapan minuman keras dari lambung ke dalam pembuluh darah bergantung pada:

1. kadar konsentrasi alkohol dalam minuman keras tersebut,

2. keberadaan cairan dan makanan lain di dalam lambung, dan

3. berat tubuh serta jenis kelamin pengkonsumsinya.

Setelah alkohol sampai ke dalam pembuluh darah, beberapa bagian tubuh akan bereaksi. Pada akhirnya zat-zat akan dipindahkan keluar dari aliran darah oleh ginjal dan hati. Laju percampuran zat dalam lambung dan perpindahan zat dalam aliran darah akan berbeda tergantung dari jenis zat penyusun pil tersebut. Berikut asumsi-asumsi yang digunakan untuk menyusun model matematika laju zat penyusun minuman keras yang terdapat dalam lambung:

1. Pemodelan dibedakan atas pola minum pengkonsumsinya.

a. Pengkonsumsi minuman keras hanya meminum satu kali dalam jumlah tertentu dan setelah itu la tidak mengkomsumsi kembali dalam jangka waktu yang cukup lama.

b. Pengkonsumsi minuman keras meminum beberapa kali dalam jangka waktu dan volume minuman keras yang konstan.

2. Setelah minuman keras masuk ke dalam lambung zat penyusunnya akan larut dan masuk ke dalam pembuluh darah, yang artinya dari lambung laju zat hanya memiliki output tunggal.

3. Laju zat yang masuk ke dalam pembuluh darah proposional dengan jumlah zat yang terdapat dalam lambung. 
4. Jumlah efektif dari level alkohol yang terkandung dalam minuman keras yang dikonsumsi bergantung pada jenis kelamin dan berat badan pengkonsumsinya.

Berdasarkan asumsi di atas, untuk kasus pengkonsumsi minuman keras hanya meminum satu kali dalam jumlah tertentu dan setelah itu la tidak mengkomsumsi kembali dalam jangka waktu yang cukup lama, diperoleh persamaan keseimbangan berikut:

$$
\left\{\begin{array}{l}
\text { Laju zat } \\
\text { alkohol } \\
\text { dalam } \\
\text { lambung }
\end{array}\right\}=\left\{\begin{array}{l}
\text { Laju zat alkohol } \\
\text { yang masuk ke } \\
\text { dalam dalam } \\
\text { lambung }
\end{array}\right\}-\left\{\begin{array}{l}
\text { Laju zat } \\
\text { alkohol yang } \\
\text { meninggalkan } \\
\text { lambung }
\end{array}\right\}
$$

Sehingga dari persamaan keseimbangan di atas di dapat model matematika sebagai berikut:

$$
\frac{d x(t)}{d t}=-k_{1} x(t), \quad \text { dengan } x(0)=x_{0} .
$$

Arti lambang dalam persamaan (1) di atas:

$$
\begin{array}{ll}
x(t) & =\text { Jumlah zat alkohol yang terdapat dalam lambung. } \\
x_{0} & =\text { Jumlah kandungan alkohol pada awal alkohol masuk ke dalam lambung. } \\
k_{1} & =\text { Proporsi zat alkohol yang terdapat dalam lambung yang masuk ke dalam pembuluh } \\
t & =\text { darah. }
\end{array}
$$

Sedangkan jika pengkonsumsi minuman keras meminum beberapa kali dalam jangka waktu dan volume minuman keras yang konstan, diperoleh persamaan keseimbangan berikut

$$
\left\{\begin{array}{l}
\text { Laju zat } \\
\text { alkohol dalam } \\
\text { pembuluh } \\
\text { darah }
\end{array}\right\}=\left\{\begin{array}{l}
\text { Laju zat alkohol } \\
\text { yang masuk ke } \\
\text { dalam pembuluh } \\
\text { darah }
\end{array}\right\}-\left\{\begin{array}{l}
\text { Laju zat alkohol } \\
\text { yang } \\
\text { meninggalkan } \\
\text { pembuluh darah }
\end{array}\right\}
$$

dengan model matematika yang bersesuaian adalah

$$
\frac{d x(t)}{d t}=I-k_{1} x(t), \quad x(0)=x_{0}
$$

dengan / menyatakan jumlah minuman keras yang dikonsumsi secara konstan tiap satuan waktu.

Selanjutnya, asumsi-asumsi yang digunakan untuk menyusun model matematika laju zat penyusun minuman keras yang terdapat dalam pembuluh darah adalah

1. Kondisi awal jumlah kandungan zat dalam pembuluh darah adalah nol.

2. Jumlah zat penyusun alkohol yang terdapat dalam pembuluh darah bertambah seiring dengan masuknya zat dari lambung.

3. Laju zat yang masuk ke dalam pembuluh darah proposional dengan jumlah zat yang terdapat dalam lambung.

4. Laju Kadar alkohol yang diserap oleh hati dari pembuluh darah adalah konstan dan tidak tergantung pada konsentrasi alkohol dalam pembuluh darah, jenis kelamin dan berat badan pengkonsumsinya. 
5. Jumlah zat penyusun alkohol yang terdapat dalam pembuluh darah berkurang karena ginjal dan hati menyerap zat tersebut dengan laju yang konstan.

6. Hati dan ginjal sebagai penyerap alkohol dalam pembuluh darah tidak rusak oleh alkohol meskipun berjumlah banyak.

Berdasarkan asumsi di atas, dapat disusun model matematika sebagai berikut:

$$
\frac{d y(t)}{d t}=k_{2} x(t)-\frac{k_{3} y(t)}{y(t)+M} \text {, dengan } y(0)=0
$$

Arti lambang dalam persamaan (3) di atas:

$x(t)=$ jumlah zat penyusun minuman keras yang terdapat dalam lambung

$y(t)=$ jumlah zat penyusun minuman keras yang terdapat dalam pembuluh darah.

$k_{2}=$ proporsi zat yang terdapat dalam pembuluh darah yang keluar ke dalam hati dan ginjal saat lambung dalam keadaan kosong.

$k_{3}=$ proporsi zat yang terdapat dalam pembuluh darah yang keluar ke dalam hati dan

ginjal saat lambung dalam keadaan isi atau saat lambung memcerna makanan lainnya.

$t \quad=$ waktu dalam satuan jam.

$M \quad=$ konstanta Michaelis-Menten.

Dalam persamaan (3) di atas koefisien $k_{2}=k_{1}$ jika lambung dalam keadaan kosong dan $k_{2}<k_{1}$ jika lambung dalam keadaan isi atau saat lambung memcerna makanan lainnya.

\section{Solusi Model dan Interpretasi}

Untuk menyelesaikan persamaan (1), ubah persamaan tersebut ke dalam bentuk

$$
\frac{d x(t)}{x(t)}=-k_{1} d t
$$

Integralkan kedua ruas dari persamaan di atas menghasilkan

$$
x(t)=e^{-k_{1} t+C}
$$

Kemudian dengan memasukkan nilai awal pada persamaan (1) didapat penyelesaian dari persamaan (1) adalah :

$$
x(t)=x_{0} e^{-k_{1} t}
$$

Selanjutnya, dengan langkah yang sama didapat penyelesaian persamaan (2) adalah

$$
x(t)=\frac{I}{k_{1}}\left(1-e^{-k_{1} t}\right)
$$

Solusi dari persamaan (3) dapat dicari dengan memanfaatkan hasil dari persamaan (4). Dengan mensubstitusikan persamaan (4) ke dalam persamaan (3) didapat persamaan

$$
\frac{d y(t)}{d t}=k_{2} x_{0} e^{-k_{1} t}-\frac{k_{3} y(t)}{y(t)+M}
$$


Dikarenakan kompleksitas persamaan (6) di atas, maka persamaan (6) disederhanakan dengan cara menggantinya dengan persamaan pendekatan menggunakan deret Taylor di sekitar nilai awalnya. Untuk keperluan tersebut didefinisikan,

$$
f(t):=k_{2} x_{0} e^{-k_{1} t}-\frac{k_{3} y(t)}{y(t)+M}, \text { dan } \frac{d y(t)}{d t}=f(0)+y(t) f^{\prime}(0)+\mathrm{E}
$$

dengan E menyatakan suku dengan orde yang lebih tinggi yang akan diabaikan. Dengan demikian maka

$$
\frac{d y(t)}{d t} \approx f(0)+y(t) f^{\prime}(0)
$$

Dengan perhitungan yang sederhana di dapat

$$
f(0)=k_{2} x_{0}, \text { dan } f^{\prime}(0)=-k_{1} k_{2} x_{0}-\frac{k_{3} y^{\prime}(0)}{M}
$$

Substitusikan hasil di atas ke dalam persamaan (7) didapat

$$
\frac{d y(t)}{d t}=k_{2} x_{0}+y(t)\left(-k_{1} k_{2} x_{0}-\frac{k_{3} y^{\prime}(0)}{M}\right)
$$

yang dapat ditulis ulang sebagai

$$
\frac{d y(t)}{d t}+y(t)\left(k_{1} k_{2} x_{0}+\frac{k_{3} y^{\prime}(0)}{M}\right)=k_{2} x_{0}
$$

Persamaan (8) merupakan persamaan diferensial dengan bentuk

$$
\frac{d y(t)}{d t}+P y(t)=Q
$$

dengan $P=k_{1} k_{2} x_{0}+\frac{k_{3} y^{\prime}(0)}{M}$ dan $Q=k_{2} x_{0}$. Sehingga dengan menggunakan teori faktor integral di dapat solusi umum dari (8) adalah

$$
y(t)=e^{-\left(k_{1} k_{2} x_{0}+\frac{k_{3} y^{\prime}(0)}{M}\right) t}\left(k_{2} x_{0} e^{\left(k_{1} k_{2} x_{0}+\frac{k_{3} y^{\prime}(0)}{M}\right) t}+C\right)
$$

Untuk mencari solusi khusus dari persamaan (9), masukkan nilai awal pada persamaan (3) ke persamaan (9) yang menghasilkan $C=-k_{2} x_{0}$.

Dikarenakan persamaan (9) masih memuat $y^{\prime}(0)$ maka untuk mencarinya perlu menurunkan fungsi (9) terhadap variabel $t$. Dengan menggunakan aturan turunan dari perkalian dua fungsi diperoleh turunan pertama dari persamaan (9) adalah 


$$
\begin{aligned}
y^{\prime}(t)= & -\left(k_{1} k_{2} x_{0}+\frac{k_{3} y^{\prime}(0)}{M}\right) e^{-\left(k_{1} k_{2} x_{0}+\frac{k_{3} y^{\prime}(0)}{M}\right) t}\left(k_{2} x_{0} e^{-\left(k_{1} k_{2} x_{0}+\frac{k_{3} y^{\prime}(0)}{M}\right) t}-k_{2} x_{0}\right) \\
& +e^{-\left(k_{1} k_{2} x_{0}+\frac{k_{3} y^{\prime}(0)}{M}\right) t}\left(k_{2} x_{0}\right)\left(k_{1} k_{2} x_{0}+\frac{k_{3} y^{\prime}(0)}{M}\right) e^{-\left(k_{1} k_{2} x_{0}+\frac{k_{3} y^{\prime}(0)}{M}\right) t}
\end{aligned}
$$

Sehingga diperoleh

$$
y^{\prime}(0)=\frac{k_{1} k_{2}^{2} x_{0} M}{M-k_{2} k_{3} x_{0}} .
$$

Substitusikan persamaan (10) ke persamaan (9) diperoleh

$$
y(t)=e^{-\left(k_{1} k_{2} x_{0}+\frac{k_{1} k_{2}^{2} k_{3} x_{0}}{M-k_{2} k_{3} x_{0}}\right) t}\left(k_{2} x_{0} e^{\left(k_{1} k_{2} x_{0}+\frac{k_{1} k_{2} x_{0}}{M-k_{2} k_{3} x_{0}}\right) t}-k_{2} x_{0}\right) .
$$

Selanjutnya, untuk dapat memaknai solusi (4), (5) dan (11) perlu dilihat perilaku ketiga fungsi tersebut melalui sajian grafik fungsinya. Namun untuk tujuan tersebut perlu diestimasi setiap parameter yang menyusun persamaan-persamaan tersebut. Merujuk pada Barnes dan Fulfor (2014), dalam Tabel 1 berikut disajikan estimasi masing-masing parameter.

Tabel 1 Estimasi parameter.

\begin{tabular}{cccc}
\hline Parameter & $\begin{array}{c}\text { Nilai } \\
\text { Estimasi }\end{array}$ & Parameter & $\begin{array}{c}\text { Nilai } \\
\text { Estimasi }\end{array}$ \\
\hline$k_{1}$ & 6 & $k_{3}$ & $0,014 \mathrm{BAL}$ \\
$k_{2}$ & 6 & $\mathrm{M}$ & $0,005 \mathrm{BAL}$ \\
\hline
\end{tabular}

Selanjutnya, dengan memasukkan parameter-parameter di atas ke dalam persamaan-persamaan solusi dan memanfaatkan program Matlab dapat disajikan grafik fungsi solusinya. Grafik fungsi (4) sebagai solusi dari model (1) disajikan dengan Gambar 1 berikut.

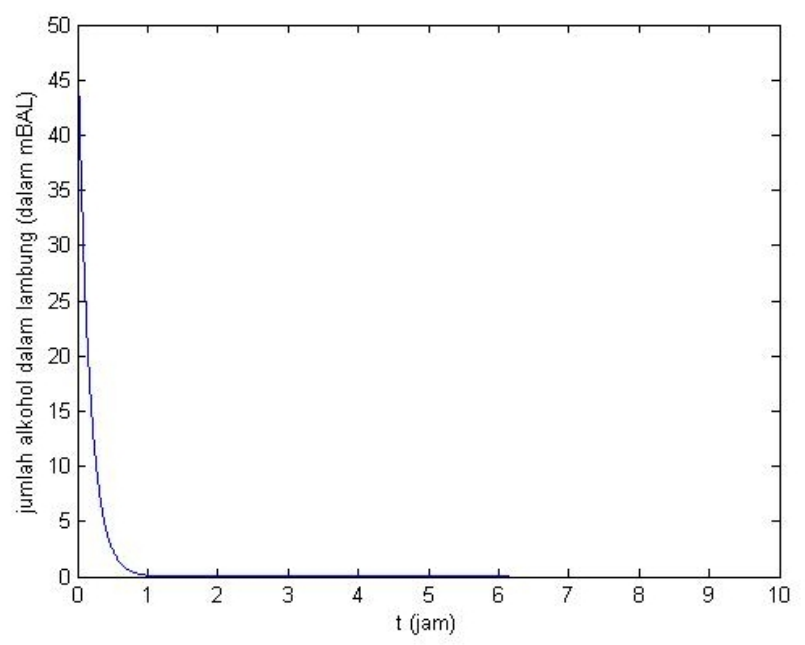

Gambar 1 Jumlah zat penyusun minuman keras yang terdapat dalam lambung. 
Dalam bahasa yang sederhana Gambar 1 menyatakan bahwa untuk waktu (t) yang semakin membesar, fungsi $x(t)$ akan terus menurun (turun monoton) hingga pada akhirnya akan menuju ke nol. Hal ini menyatakan bahwa untuk waktu yang semakin lama jumlah zat penyusun minuman keras yang terdapat dalam lambung semakin lama akan semakin habis meninggalkan lambung menuju ke

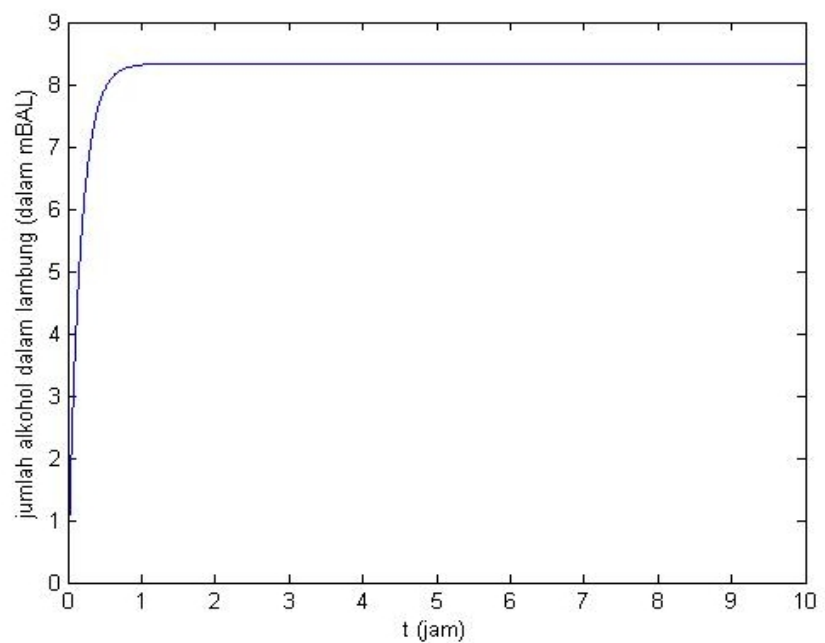

Gambar 2 Jumlah zat penyusun minuman keras yang terdapat dalam lambung. pembuluh darah. Sedangkan grafik fungsi (5) sebagai solusi dari model (2) yang menyatakan jumlah zat penyusun minuman keras yang terdapat dalam lambung jika pengkonsumsi minuman keras meminum beberapa kali dalam jangka waktu dan volume minuman keras yang konstan disajikan oleh Gambar 2.

Gambar 2 menyatakan bahwa untuk waktu (t) yang semakin membesar, fungsi $x(t)$ akan stabil pada suatu nilai tertentu, yang besarnya bersesuaian dengan jumlah alkohol yang dikonsumsi secara rutin. Hal ini menyatakan bahwa untuk waktu yang semakin lama jumlah zat penyusun minuman keras yang terdapat dalam lambung akan berjumlah tetap dan menuju ke pembuluh darah.

Berikutnya, grafik fungsi (11) sebagai solusi dari model (3) yang menyatakan jumlah zat penyusun minuman keras yang terdapat dalam pembuluh darah disajikan oleh Gambar 3 berikut.

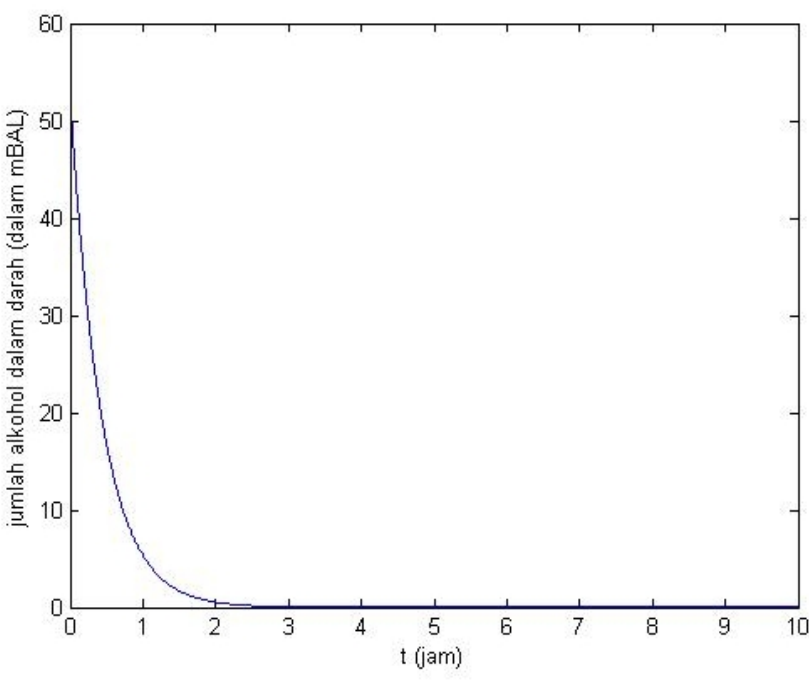

Gambar 3 Jumlah zat penyusun minuman keras yang terdapat dalam pembuluh darah.
Berdasarkan Gambar 3 terlihat bahwa untuk waktu (t) yang semakin membesar, fungsi $y(t)$ akan terus menurun (turun monoton) hingga pada akhirnya akan menuju ke nol. Hal ini menyatakan bahwa untuk waktu yang semakin lama jumlah zat penyusun minuman keras yang terdapat dalam pembuluh darah semakin lama akan semakin habis diserap oleh hati dan ginjal. Ketika alkohol sampai ke pembuluh darah maka akan menimbulkan reaksi psikis pada pengkonsumsinya. Oakley dan Ksir (1993) memaparkan efek dan gejala yang ditimbulkan oleh alkohol pada diri pengkonsumsinya, baik fisik maupun psikis sebagaimana yang disajikan dalam Tabel 2. Satuan BAL (blood alcohol level) mengukur banyaknya kadar/konsentrasi alkohol dalam darah dengan satuan gram alkohol/100 ml darah. Sehingga jika terdapat $100 \mathrm{mg}$ alkohol per $100 \mathrm{ml}$ darah maka disajikan sebagai 0.1 BAL.

Tabel 2 Efek dan gejala pengkonsumsi alkohol.

BAL Efek pada Perilaku

0.05 Sikap kewaspadaan yang rendah, punya kecenderungan berperasaan gembira (good feeling), merasa terlepas dari hambatan-hambatan hidup, kemampuan memutuskan sesuatu melemah.

\section{Gejala Fisik dan Psikis}

Pandangan kabur, senang, merasa paling hebat. 
0.10 Reaksi fisik terhadap rangsangan rendah, fungsi motorik melambat, kesadaran diri melemah.

0.15 Menampilkan ketidakkonsistenan dalam bereaksi terhadap rangsangan.

0.20 Terdapat tanda-tanda depresi perilaku, bergerak dengan tanpa kendali, tampak tegas dalam keadaan mabuk.

0.25 Mempunyai gangguan motorik yang parah, tubuh bergoyang dan kehilangan keseimbangan, sensor-sensor tubuh sangat terganggu.

0.30 Tidak memiliki kesadaran yang komprehensif terhadap apa yang sedang terjadi.

0.35 Tidak sadarkan diri, sebagaimana seorang yang di operasi bedah.

0.40 Dapat menyebabkan kematian.
Perasaan terancam dan memposisikan diri sebagai seorang yang berwatak jahat.

Pusing.

Gangguan motorik tubuh.

Timbul perasaan membenci diri sendiri dan badan terasa kusut.

Mengigau dan mengalami disorientasi diri.

Mabuk berat hingga tak sadarkan diri.

Mati.

Berdasarkan Tabel 2 di atas terlihat bahwa alkohol mulai menimbulkan gangguan fisik dan psikis ketika kapasitasnya di atas $0.05 \mathrm{BAL}$. Oleh karena itu hampir semua negara di dunia ini melarang warga negaranya mengemudi kendaraan jika la mengkonsumsi alkohol di atas ambang tersebut.

\section{Kesimpulan}

Makalah ini telah mengkaji pemodelan jumlah zat penyusun minuman keras, yaitu alkohol, dalam tubuh pengkonsumsinya. Perumusan model didasarkan pada kasus mengkonsumsi minuman keras sekali ataupun secara rutin, begitu juga dengan memandang apakah di dalam lambung pengkonsumsi terdapat zat makanan lain ataupun tidak. Berdasarkan model yang didapat dapat dianalisa perubahan jumlah alkohol baik di dalam lambung maupun di dalam pembuluh darah.

Model matematika yang dikonstruksikan dalam makalah ini masih memandang pengkonsumsi sebagai satu entitas tunggal dan tidak membedakan jenis kelamin maupun berat badannya. Sehingga perumusan model yang mengakomodasi jenis kelamin maupun berat badan pengkonsumsinya menjadi masalah terbuka yang dapat diteliti lebih lanjut.

\section{Ucapan Terimakasih}

Alhamdulillah, akhirnya dapat diselesaikan penelitian ini. Untuk itu disampaikan ucapan terima kasih yang sebesar-besarnya kepada:

1. LPPM UIN Sunan Kalijaga Yogyakarta yang telah mendanai kegiatan ini.

2. Para pihak yang tidak dapat disebutkan satu-persatu yang turut andil dalam proses pelaksaaan penelitian ini hingga pembuatan laporannya.

\section{Referensi}

[1] Barnes, B dan Fulfor, G.R., Mathematical Modelling with Case Studies: Using Maple and MATLAB, CRC Press, 2014.

[2] Borelli R, C. Coleman, Differential Equation: A Modelling Perspective, New York Wiley 1996.

[3] Bhunu, C. P., A mathematical analysis of alcoholism, World Journal of Modelling and Simulation, vol. 8, no. 2, pp.124-134, 2012.

[4] Chapman, S.J., Multiscale Mathematical Modelling In Medicine And Biology, OCIAM Mathematical Institut, 2009. 
[5] Faisant, N., Siepmann, F., Richard, J, and Benoid, J.P., Mathematical modeling of drug release from bioerodible microparticles: effect of gamma-irradiation, European Journal of Pharmaceutics and Biopharmaceutics, vol. 56, pp. 271 - 279, 2003.

[6] George, K., Kubota, K., and Twizell, E.H., A two-dimensional mathematical model of percutaneous drug absorption, BioMedical Engineering OnLine, vol. 3:118, 2004.

[7] Heck, A., Modelling Intake and Clearance of Alcohol in Humans, The Electronic Journal of Mathematics and Technology vol. 1, no. 3, 2007.

[8] Lee, A.J., J.R. King., S Hibred., Mathematical Modelling Of The Release Of Drug From Porous, Nonswelling Transdermal Drug-Delivery Devices, Oxford Journal Mathematical Medicine and Biology, 1997.

[9] Muller, Melanie., Nonlinear Pharmacokinetict of MDMA and Its Major Metabolities in Sequirrel Monkeys at Plasma Concentration of MDMA that Develop After Typical Psicoactive Doses, The Journal Pharmacologies and Experimentals Therapeutic, 2008.

[10] Oakley R, C. Ksir, Drugs, Society and Human Behaviour, St Louis HO, 1993.

[11] Siepmann, J., Siepmann, F., Mathematical modeling of drug delivery, International Journal of Pharmaceutics, vol. 364, pp 328 - 343, 2008.

[12] Tzafriri, A.R., Lenner, E.I., Barac, M.F., Hinchcliffe, M., and Parnas, H., Mathematical Modeling and Optimization of Drug Delivery from Intratumorally Injected Microspheres, Clinical Cancer Research, vol. 11, 2005. 